\title{
The Effect of Slope on the Infiltration Capacity and Erosion of Mount Merapi Slope Materials
}

\author{
Anselma Diksita Prajna Duhita ${ }^{1}$, Adam Pamudji Rahardjo ${ }^{1, *}$, Ani Hairani ${ }^{2}$ \\ ${ }^{1}$ Department of Civil and Environmental Engineering, Universitas Gadjah Mada, Yogyakarta, INDONESIA \\ Jalan Grafika No 2 Yogyakarta \\ 2 Department of Civil Engineering, Universitas Muhammadiyah Yogyakarta, Yogyakarta, INDONESIA \\ Jl. Brawijaya, Geblagan, Tamantirto, Kasihan, Bantul, Yogyakarta \\ "Corresponding authors: rahardjo.adam@ugm.ac.id
}

SUBMITTED 3 August 2020 REVISED 19 August 2020 ACCEPTED 18 September 2020

\begin{abstract}
The infiltration on slopes has a specific behavior capable of being parameterized and one of the reasons is due to the ability of the slope to generate less ponding on the sloping soil surface. This, therefore, affects infiltration rate and surface runoff proportion of water from any kind of rainfall distribution and the tendency of the surface runoff to be higher usually leads to a higher erosion rate on the slope. Moreover, slope steepness is the most important parameter of a slope, and its effect at $36 \%$, $47 \%$, and $58 \%$ was tested on the infiltration capacity and erosion rate of Mt. Merapi bare slope material in a laboratory using a rainfall simulator. The rainfall intensity was set constant at a rate of $116.31 \mathrm{~mm} /$ hour while the infiltration rate was measured by the volumetric balance principle and the erosion rates by collecting the eroded grains at the downstream end flume. Furthermore, the infiltration capacity was evaluated using the Horton method by fitting the equation to the recorded infiltration rate data while the average erosion was through the eroded grain data for each test. The results obtained represent the relationship between slope steepness, the affected infiltration capacity, and erosion for each test, and the infiltration capacity was found to be decreasing in lower slope $<47 \%$ and increasing in a higher slope while the erosion rate was increasing between $7 \%$ and $15 \%$ for each $1 \%$ increase in the slope steepness. In addition, polynomial and linear equations were developed to express the relationship between these three indicates at the Mt. Merapi bare slope material.
\end{abstract}

KEYWORDS Slope Steepness; Infiltration Capacity; Erosion Rate; Rainfall Simulator; Mount Merapi Slope Materials.

(C) The Author(s) 2021. This article is distributed under a Creative Commons Attribution-ShareAlike 4.0 International license.

\section{INTRODUCTION}

\subsection{Background}

Infiltration is defined as the movement of water into the soil due to gravity and capillary forces (Bedient and Huber, 1992). It is one of the processes in the hydrological cycle which determines the amount of rainwater entering the soil and those forming surface runoff. This means infiltrated water either becomes the interflow or accumulates underneath the soil layer with the infiltration of more water reported to usually leads to lesser surface runoff. The process is mostly affected by several factors such as soil conditions and properties, surface cover and condition as well as the intensity and duration of the rain (Harto, 2000) which interact with each other to make infiltration a complex process. Moreover, in the situation rainfall intensity is lower than the ability of the soil to infiltrate water, all the rainwater is infiltrated while a pond is formed in a case where soil ability was unable to infiltrate water, thereby, causing runoff on the soil surface (Liu et al., 2011; Lei et al., 2006). There are different kinds of ground surface morphology with several surface plains found to have varying elevations connected by slopes (Schor and Gray, 2007). Meanwhile, the slope has a steepness, expressed in percent or degree, which represents the ratio of the vertical plane to the horizontal plane. The occurrence of infiltration on slopes has a specific behavior due to the generation of less pond on the soil surface (Della Sala, 2014; Lei et al., 2006). This further affects the proportion of rainwater volume infiltrating and those forming surface runoff. Another process observed to be occurring on a slope is erosion and it is defined as the removal of the soil surface layer by agencies such as wind, water, or ice (Schor and 
Gray, 2007). Soil erosion involves the process of detachment and transportation of the soil particle by these agencies. It is initiated by drag, tractive, or impact forces acting on the soil surface particles. Schwab et al. (1993) in Smount (1994) mentioned four main factors affecting erosion to be weather, soil, vegetation, and topography. Meanwhile, several types of water erosion have also been identified to be raindrop splash, sheet erosion, rill erosion, gullying, and stream channel (Schor and Gray, 2007; Smount, 1994). Raindrop splash occurs due to the impact of raindrops on the surface of the soil which causes some soil particles to be splashed into the air while sheet erosion is the removal of soil on a slope in the form of a thin layer or sheet. Moreover, rill erosion is defined as the removal of soil by water from the small concentrated of overland flow, gullying is intermittent flow erosion which is larger than rill while stream channel erosion is the removal of soil from stream banks and scouring of sediment from the beds. Infiltration, surface runoff, and surface erosion processes are important in several aspects such as water and soil conservation as well as land regulation and protection (Ran et al., 2018). The processes have also been reported to be affected by some factors such as rainfall characteristics, topography, soil characteristics, and land use. It is, however, possible to determine the rainfall-runoff process through field and laboratory tests (Lei et al., 2006).

Several studies have been conducted on the effect of slope on the infiltration capacity and erosion in advance. For example, the effect of soil type, peat, slope, compaction effort, and their interactions on infiltration, runoff, and raindrop erosion of some Trinidadian soils was studied by Ekwue and Harrilal (2010). Another study by Joshi and Tambe (2010) estimated the infiltration rate, run-off, and sediment yield under simulated rainfall experiments in Upper Pravara Basin, India with the focus on the effect of slope angle and grass-cover. Moreover, the impact of slope gradient on soil surface features and infiltration on steep slopes in Northern
Laos was researched by Ribolzi, et.al (2011) while the effects of tillage practices and slope on runoff and erosion of soil from the loess plateau were studied by Wang, et.al (2017). This study was, therefore, conducted based on a laboratory test with a rainfall simulator for soil samples from Mount Merapi bare slope materials at Bebeng River, especially the upstream of the BE-D4 Dam, Kemiren, Srumbung, Magelang, Central Java as shown in Figures 1 and 2. This location was selected because it was affected by Mount Merapi lahars in the last three years (BNPB, 2016) and this study is expected to show the water and sediment dynamic phenomena on its slope to ease the further investigation of lahar floods incidence. There are important questions required by this research to be answered on the Mount Merapi bare slope materials and these include "what is the mechanism of infiltration and erosion?" and "what is the effect of slope on infiltration capacity and erosion?" These were used to determine the relationships between slope steepness, infiltration capacity, and erosion rate. However, several assumptions were made such as the use of a bare slope which is unaffected by vegetation, rainfall intensity is limited by the simulator capacity, the size of the model is sufficient to represent the field condition and grain size distribution while the specific gravity, water content, density, and volume of the test soil are fixed variables.

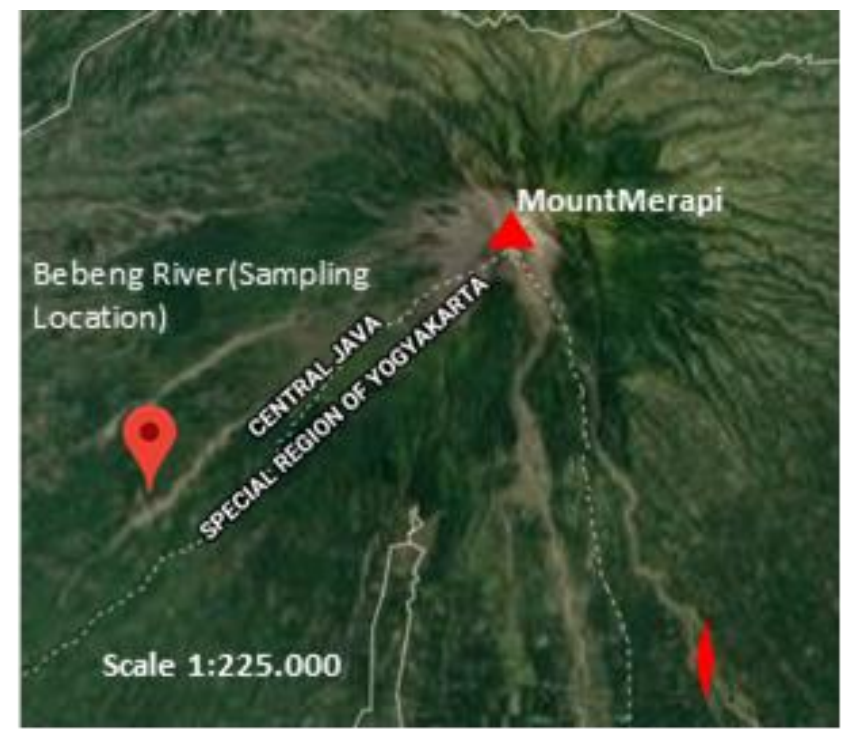

Figure 1. Material sampling location. 


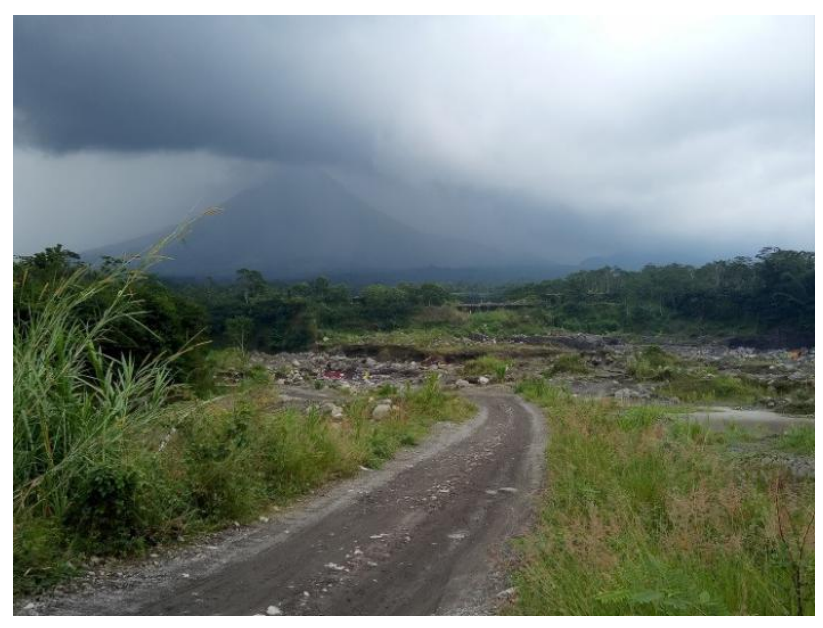

Figure 2. View of material sampling location.

\section{METHODS AND THEORIES}

\subsection{Literature Review of Condition of Material Sampling Location}

The grain size distribution of surface soil on Mount Merapi slope varies and grouped based on the distance from the peak as observed from the three classifications of (De Bélizal et al., 2013) which are 5-10 km known as the proximal zone, $10-15 \mathrm{~km}$ as medial zone, and $15-20 \mathrm{~km}$ as the distal zone. Most of the grains are coarse, contain less clay, and the average size at a location is finer at a further distance from the peak. Bebeng River is in the proximal to medial zone (De Bélizal et al., 2013) which contains rocks with more varied distribution while the distal zone ranges from gravel to fine materials. (Selles, 2014) also classified the Mount Merapi landscape based on its distance from the peak and the central zone was found to be on $2000 \mathrm{~m}$ or more above sea level at a slope angle ranging between $40^{\circ}-80^{\circ}$, the proximal zone has $20^{\circ}$ $30^{\circ}$, the medial zone has $10^{\circ}-20^{\circ}$, and the distal zone has below $10^{\circ}$.

Rainfall data were collected from the record of a remote monitoring system which belongs to the Hydraulic Laboratory of Civil and Environmental Engineering Department UGM and the BE-D4 automatic rain gauge station located adjacent to the sampling location. The annual rainfall was observed to range between 1855 to $2549 \mathrm{~mm}$ from 2016 to 2018 and the highest monthly and daily rainfall were $420 \mathrm{~mm}$ and $100 \mathrm{~mm}$ respectively. Moreover, the annual highest rainfall intensity ranged between 100 $\mathrm{mm} /$ hour to $132 \mathrm{~mm} /$ hour while the automatic rainfall gauge was used to provide a five-minute rainfall data sequence in $\mathrm{mm} /$ hour.

The runoff-rainfall ratio or runoff coefficients calculated based on the effective rainfall on Mount Merapi slopes ranged between $4.4 \%$ and 11.9\% (Ningsih and Purnama, 2012; Selles, 2014) while the infiltration rate after the 2010 Merapi eruption was between 0.051 and 0.487 $\mathrm{cm} /$ minute which is equivalent to $30.6 \mathrm{~mm} /$ hour and $292.2 \mathrm{~mm} /$ hour.

\subsection{Sampling of Materials}

The samples were obtained from 4 spots not covered by any vegetation at the location and selected using the random sampling method. The physical parameters of the samples were tested and $10.54 \%$ was averagely obtained for water content, $0.933 \mathrm{~g} / \mathrm{cm}^{3}$ for dry density, 2.72 for specific gravity, $42.38^{\circ}$ for internal friction angle, and $0.066 \mathrm{kN} / \mathrm{m}^{2}$ for the cohesion. Moreover, the sample grain size distributions were found to be poorly graded sands with 1.094 for $\mathrm{Cu}$ and 7.658 for $\mathrm{Cc}$. Meanwhile, the sample and experimental materials grain size distribution charts are presented in Figure 3 with the experimental values used as the average for the sample materials. 


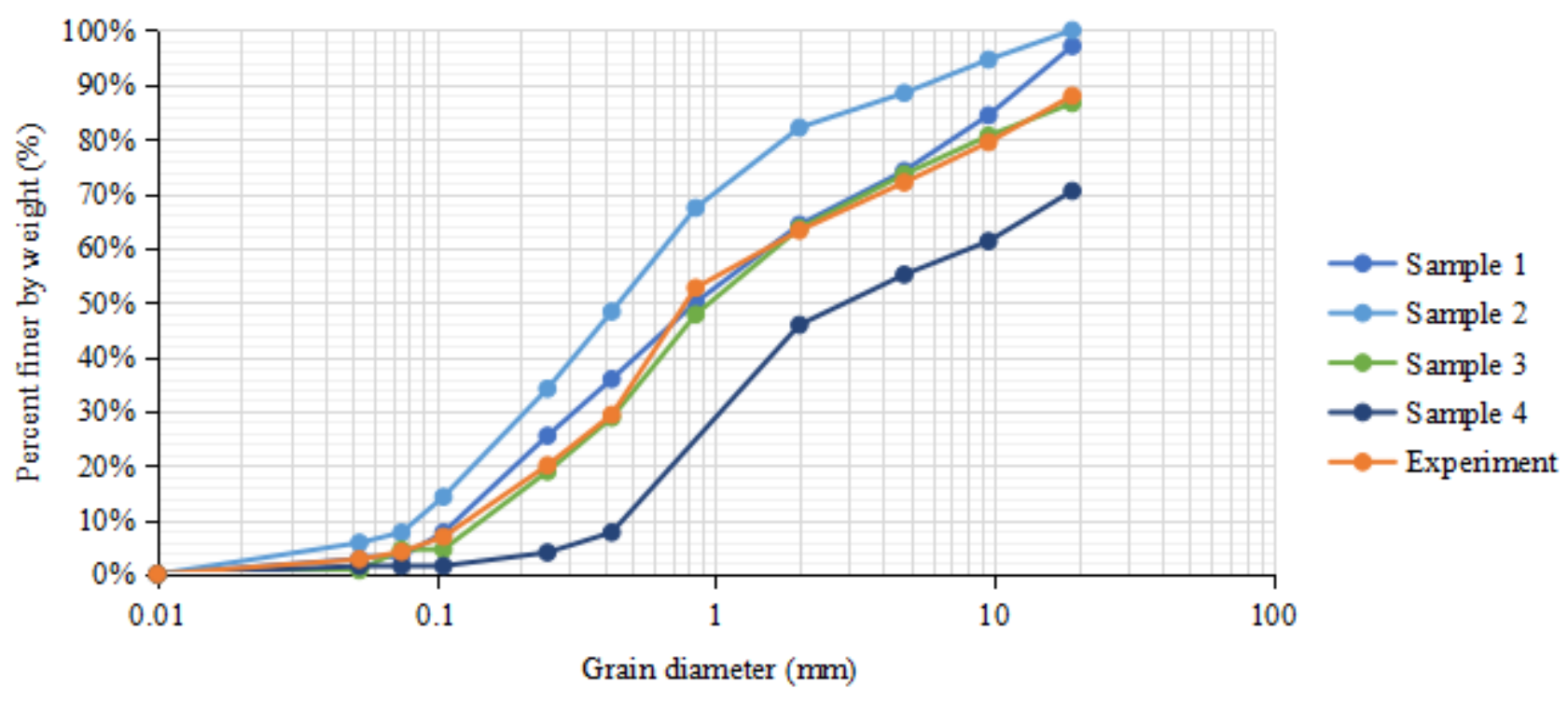

Figure 3. The grain size distribution of samples and experiment materials.

\subsection{Calibration of Rainfall Simulator}

The type of rainfall simulator apparatus used for the test was nozzle rainfall force as shown in Figure 4 and observed to have a falling height of $8 \mathrm{~m}$. Moreover, a $1.5 \mathrm{~m} \times 0.75 \mathrm{~m}$ sloping flume was applied and the simulator was calibrated to determine the rain intensity and spatial distribution generated at a certain pump power setting used during the test.

The rainfall intensity of the area was measured by collecting the raindrops in several small cylindrical tanks as rain gauges at evenly distributed points over a certain time interval due to the impossibility of collecting rainwater for the entire area at a time. The values were expressed as rainfall depth over a predefined period (Triatmodjo, 2008) and multiplied by a reduction factor to correct the possibility of having values that are too high.

The rainfall data from five rain gauges located in a catchment area has the ability to improve the accuracy of the values for the rainfall in the sloping flume. They were further used to calibrate the rainfall intensity recorded at a point just outside the sloping flume to represent the rainfall over the sloping flume as shown in Figure 5.

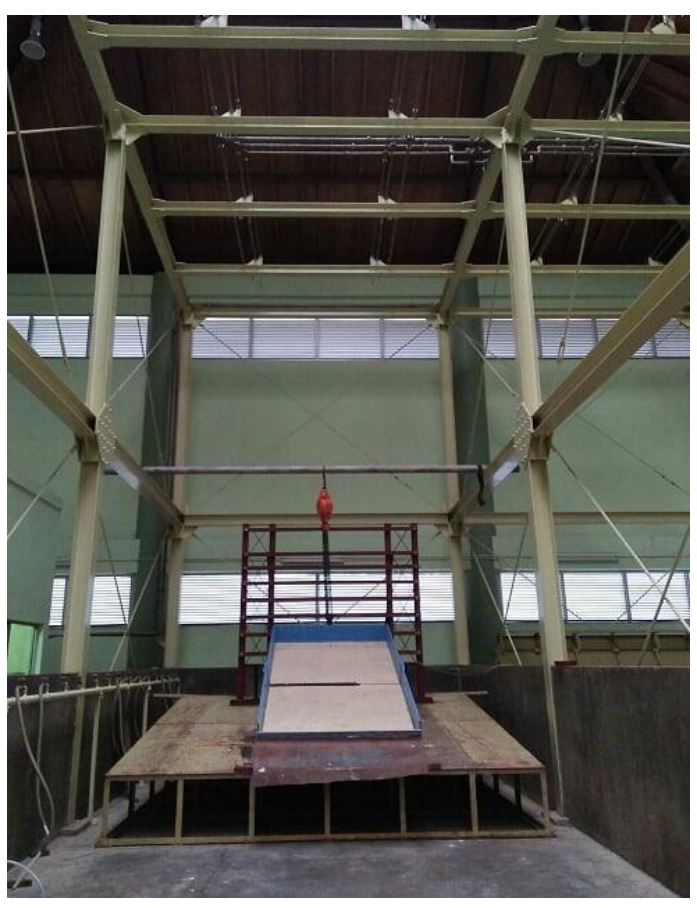

Figure 4. Rainfall simulator and sloping flume. 


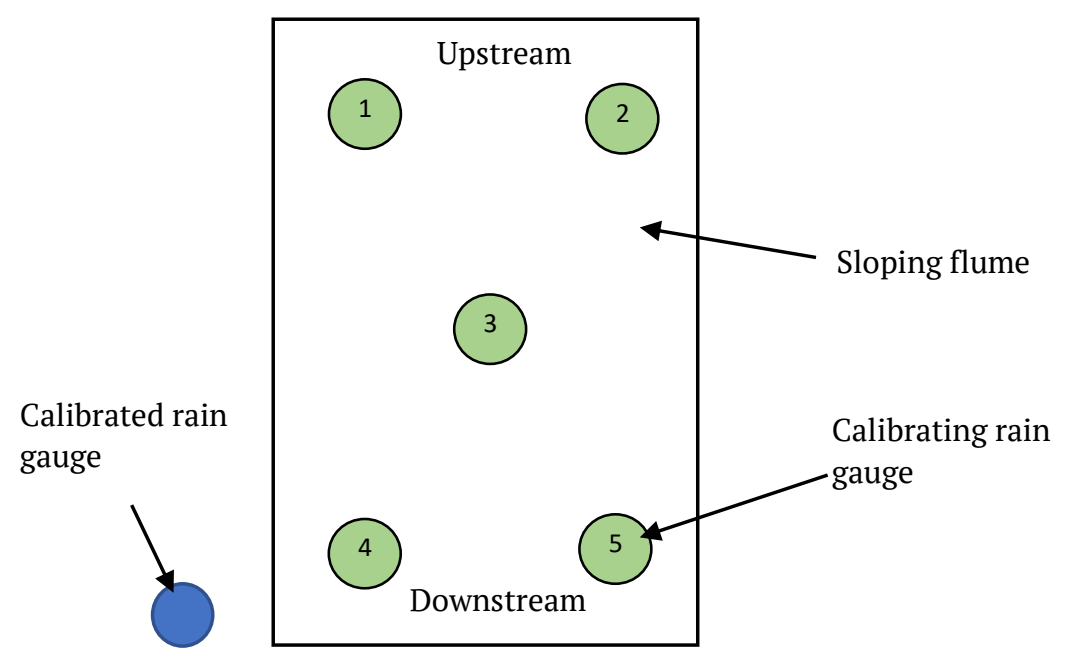

Figure 5. Location of rain gauge stations on the sloping flume during calibration.

The rainfall data from the rain gauges have a certain percentage of error or deviation from the average values and a lower value indicates the number of the rain gauges installed is better to represent the average rainfall of the catchment area. Some equations have, however, been proposed by (Santosh, 2007) to determine the error percentage as shown in Equations (1) and (2).

$N=\left(\frac{C_{v}}{E}\right)^{2}$

$C_{v}=\frac{100 \sigma}{P}$

where $N$ is the number of rain gauges, $C_{v}$ is the coefficient of rainfall variation based on the existing rain gauge stations, $E$ is the error percentage, $P$ is the average rainfall and $\sigma$ is the standard deviation value. Meanwhile, the configuration in Figure 5 has an error percentage of $22 \%$. Moreover, the spatial uniformity of rainfall data is represented by a uniformity coefficient provided by Christiansen (1942) in Jones, et.al (2017) as formulated in the following equation.

$C_{u}=100\left(1-\frac{\sum_{i=1}^{n}\left|x_{i}-\dot{x}\right|}{n \dot{x}}\right)$

where $\mathrm{C}_{u}$ is Christiansen's uniformity coefficient, $\mathrm{n}$ is the number of observations, $X_{i}$ is the rainfall data measured from rain gauge station $i$, and $\dot{X}$ is the average rainfall data of all the stations. Meanwhile, the uniformity coefficient of the configuration in Figure 5 was 90.53\%.

The rainfall intensity rate from the flume was approximated using rainfall gauge data while the value for each gauge was obtained from the volume of the accumulated rainwater in the stations during the calibration run divided by the gauge area and duration of calibration run. Several methods can be applied to convert the point rainfall data from different rain gauges within and surrounding an area to rainfall data and these include the arithmetic average, inverse square distance weighting (IDW) (Prayuda, 2012), Thiessen, and the isohyet methods (Harto, 2000). The arithmetic average method is very simple but does not consider the spatial distribution effect of the rain gauges while the IDW interpolates the rainfall value at any location based on rainfall data of all gauges and integrates the interpolated values throughout the area. Moreover, the Thiessen method considers the influenced area of each rain gauge by drawing boundary polygons based on the equal distance between the neighboring gauges. This method is relatively simple, popular, and has been used in similar laboratory experiment study to investigate the effect of rainfall wetting on slope stability (Ariesta, 2019). Meanwhile, the isohyet method was used in this study to determine the average rainfall intensity on the sloping flume by drawing the contour lines or isohyet based on rainfall data of all gauge stations using interpolation principles 
through the use of Surfer Software, and the results are presented in Figure 6. The contour line values were observed to have started from 85 to $145 \mathrm{~mm} /$ hour with a $5 \mathrm{~mm} /$ hour interval as shown in column 1 of Table 1 . Furthermore, the areas of each influenced zone of a contour line which is between $-2.5 \mathrm{~mm} /$ hour line and +2.5 $\mathrm{mm} /$ hour line were measured and used to calculate the isohyet ratio presented in column 2 and found to be equal to the influenced zone area divided by the total area or sum of all influenced zone areas. These ratios or values were further used as weighting factor of each contour line value while the design rainfall intensity on the sloping flume is the summation of all weighted rainfall intensity of contour lines as indicated in column 3 .

The design rainfall intensity falling on the sloping flume was expected to reach the annual highest values of the sampled location on Mt. Merapi slope which was recorded to be between 100 to $132 \mathrm{~mm} /$ hour while the average value was expected to be achieved by setting the pump of rainfall simulator at $45 \%$ full power.

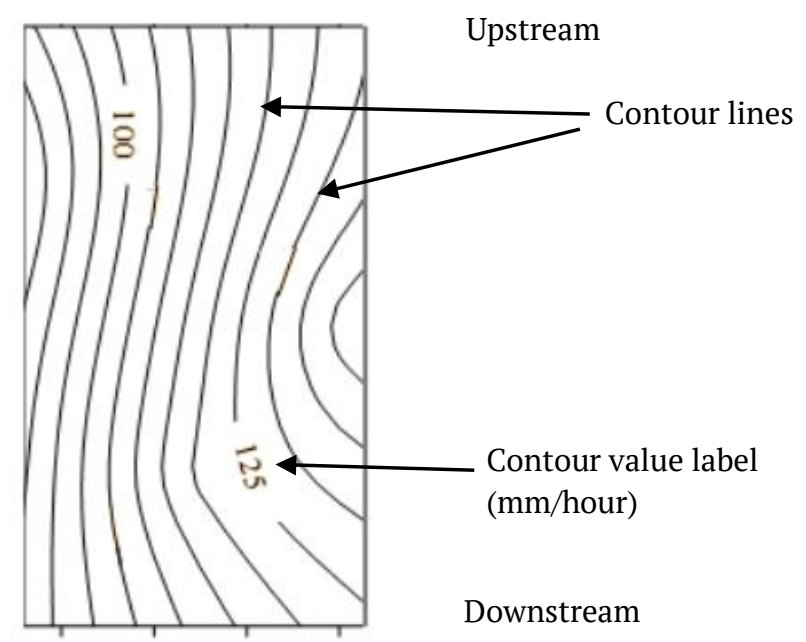

Figure 6. The isohyet (in $\mathrm{mm} /$ hour) on the sloping flume at the calibration run.
Table 1. Averaged rainfall value calculation

\begin{tabular}{lll}
\hline $\begin{array}{l}\text { Intensity of } \\
\text { interval area } \\
\text { (mm/hour) }\end{array}$ & $\begin{array}{l}\text { Isohyet } \\
\text { Ratio }\end{array}$ & $\begin{array}{l}\text { Weighted Intensity } \\
\text { (mm/hour) }\end{array}$ \\
\hline 85 & 0.021 & 1.744 \\
90 & 0.059 & 5.284 \\
95 & 0.088 & 8.406 \\
100 & 0.086 & 8.594 \\
105 & 0.089 & 9.441 \\
110 & 0.089 & 9.930 \\
115 & 0.092 & 10.676 \\
120 & 0.105 & 12.721 \\
125 & 0.118 & 14.965 \\
130 & 0.117 & 15.427 \\
135 & 0.090 & 12.396 \\
140 & 0.036 & 5.084 \\
145 & 0.011 & 1.644 \\
\hline Design Rainfall Intensity: & 116.312 (mm/hour) \\
\hline
\end{tabular}

\subsection{Infiltration and Erosion Test}

The test was conducted on $36 \%$ slope steepness with a $20^{\circ}$ angle, $47 \%$ with $25^{\circ}$, and $58 \%$ with $30^{\circ}$. The slope was determined based on the ranges recorded from the sampling locations and a test was run thrice for each slope while the pump was set at $45 \%$ full power to generate an average rainfall intensity of $116.3 \mathrm{~mm} /$ hour with a minimum of $97.7 \mathrm{~mm} /$ hour and a maximum of $138.5 \mathrm{~mm} /$ hour.

The base of the sloping flume was covered by a gravel layer to drain percolated water and a fabric separator layer was placed on top of the gravel layer to keep the grains of experiment material at the top. Meanwhile, the test material was set in air-dry condition at the beginning of each experiment run, poured in a container, and compacted to reach the density of sampling location which is at a $10 \mathrm{~cm}$ thick layer. 
An eroded material collector was set at the downstream end of the sloping flume and the rainfall simulator was turned on and waited for the rainfall intensity to reach the steady condition. The infiltration rate was measured with the Horton method using the volumetric balance principle while the erosion rates were evaluated by collecting the eroded grains at the downstream end flume during the test for 2 hours.

\subsection{Data Analysis}

The dynamism of the infiltration rate is estimable using several equations and the most simple and easily understood is the (Horton, 1933) equation which is shown as follows:

$f(t)=f_{c}+\left(f_{0}-f_{c}\right) e^{-k t}$

where $f(t)$ is the infiltration rate as a function of time $(\mathrm{cm} / \mathrm{s}), f_{0}$ is the initial infiltration rate $(\mathrm{cm} / \mathrm{s}), f_{c}$ is the final infiltration rate $(\mathrm{cm} / \mathrm{s}), k$ is the empirical constant $\left(\mathrm{s}^{-1}\right)$, and $t$ is time (s).

The application of Horton's equation requires determining the $f_{0}, f_{c}$, and $k$ parameters. The $f_{0}$ value was set to be the first or initial infiltration rate data while $f_{c}$ and $k$ were determined by trial error or any optimization procedure to ensure the Horton's curve has the best fit to the data using the fitting method. The detailed criteria of best fit are, however, explained in the next section. Meanwhile, Horton's equation is an exponential function which shows the infiltration rate in the soil to be decreasing with time as shown in Figure 7. Each soil has its asymptotic value which represents the final rate of infiltration and this is defined as the infiltration capacity.

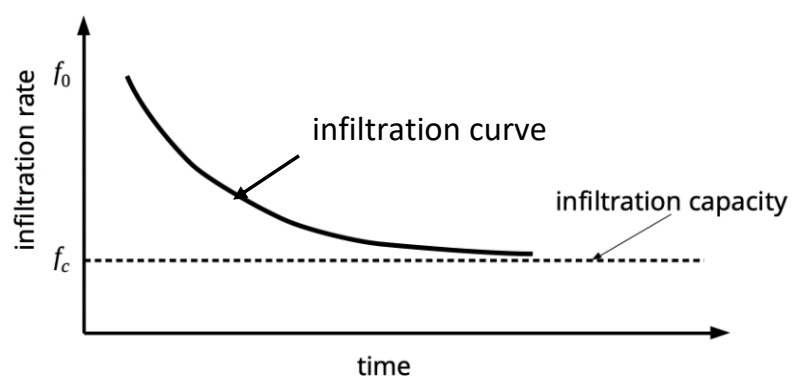

Figure 7. Theoretical infiltration decay curve.
The infiltration rate used in this study was determined by subtracting the runoff volume from the rainfall volume for each experiment run time interval and later divided the value by flume area and time interval duration. Moreover, the Least Square Method (LSM) was used in the optimization procedure to obtain the best-fitted Horton equation parameters, $f_{0}$, $f_{c}$, and $k$, for each test. This procedure minimized the sum of squares of the difference between the observed and Horton's equation function values for all the sampled data. The LSM is, however, identical to the Root Mean Square Error (RMSE) method with the value to be minimized or the error value using RMSE Method presented in Equation (5). It is possible to conduct this minimizing process using the solver add-in in the Microsoft Excel software. The infiltration capacity, $f_{c}$, was, therefore, obtained after optimizing the Horton's equation to the recorded infiltration rate data.

$N=\sqrt{\frac{\sum_{1}^{n}\left|f_{i}-f(x)_{i}\right|^{2}}{n}}$

where $R$ is the RMSE value to be minimized, $f_{i}$ is the $i^{\text {th }}$ (time steps) observed infiltration data, $f(x)_{i}$ is the Horton's function value for the $i^{\text {th }}$ data (discrete-time), and $n$ is the number of data.

The efficiency of the results obtained from an experiment can be determined using several methods and an example is a Nash-Sutcliffe efficiency (NSE) which was used in this study based on Equation (6) (Nash \& Sutcliffe, 1970). NSE value ranges from $-\infty$ to 1 and the data becomes more acceptable as the value is closer to 1 . The NSE equation was used in this study to determine the infiltration rate efficiency between the observed and simulated data from the Horton equation.

$N S E=1-\left[\frac{\sum_{i=1}^{n}\left(Y_{i}^{\text {obs }}-Y_{i}^{\text {simu }}\right)^{2}}{\sum_{i=1}^{n}\left(Y_{i}^{\text {obs }}-Y_{i}^{\text {mean }}\right)^{2}}\right]$

where $Y^{\text {obs }}$ is the observation data, $Y_{i}^{\text {simu }}$ is the simulated value, and $Y^{\text {mean }}$ is the mean value of the observed data. 
The surface erosion can be in the form of individual grain erosion due to excess bed shear stress (Miedema, 2012) or mass erosion which has the ability to cause a surface landslide and debris flow (Fathani, Syah, and Faris, 2019). The erosion scale used in this study was, however, not up to mass erosion but include excess bed shear stress which causes surface grain erosion and raindrop splash (Farmer, 1971).

\section{RESULTS}

\subsection{Infiltration Experiment Results}

Three tests were conducted on each slope steepness in this study using the infiltration rate equations constructed using Horton's method for all tests. Moreover, the fitting of the change in the recorded infiltration rate to Horton's equation was obtained by determining the most appropriate values of $f_{c}$ and $k$ values providing the minimum RMSE value of the recorded data to the Horton's equation for all test data is as shown in Table 2. The parameter $f_{0}$ was set as the initial infiltration rate data.

The Horton curves for $36 \%$ slope steepness is shown in Figure 8, 47\% in Figure 9, and 58\% in Figure 10.

Table 2. The results of parameter optimization of Horton's equation of each test run.

\begin{tabular}{lllllll}
\hline $\begin{array}{l}\text { Slope } \\
(\%)\end{array}$ & $\begin{array}{l}\text { Test run } \\
\text { number }\end{array}$ & $\begin{array}{l}f_{c} \\
(\mathrm{~mm} / \text { hour })\end{array}$ & $\begin{array}{l}f_{o} \\
(\mathrm{~mm} / \text { hour })\end{array}$ & $k$ & $\begin{array}{l}\text { Min RMSE } \\
(\mathrm{mm} / \text { hour })\end{array}$ & $\begin{array}{l}\text { NSE } \\
(\%)\end{array}$ \\
\hline & 1 & 102.857 & 116.312 & 0.313 & 1.44 & 0.580 \\
36 & 2 & 105.737 & 115.299 & 0.223 & 0.76 & 0.545 \\
& 3 & 93.350 & 115.299 & 0.661 & 5.04 & 0.509 \\
& 1 & 58.003 & 113.900 & 0.141 & 3.17 & 0.765 \\
47 & 2 & 74.481 & 113.619 & 0.573 & 4.89 & 0.868 \\
& 3 & 82.388 & 114.605 & 0.155 & 3.81 & 0.707 \\
& 1 & 109.250 & 114.833 & 1.378 & 1.34 & 0.344 \\
58 & 2 & 91.317 & 113.619 & 0.184 & 1.83 & 0.870 \\
& 3 & 109.320 & 114.605 & 1.756 & 1.62 & 0.267 \\
\hline
\end{tabular}
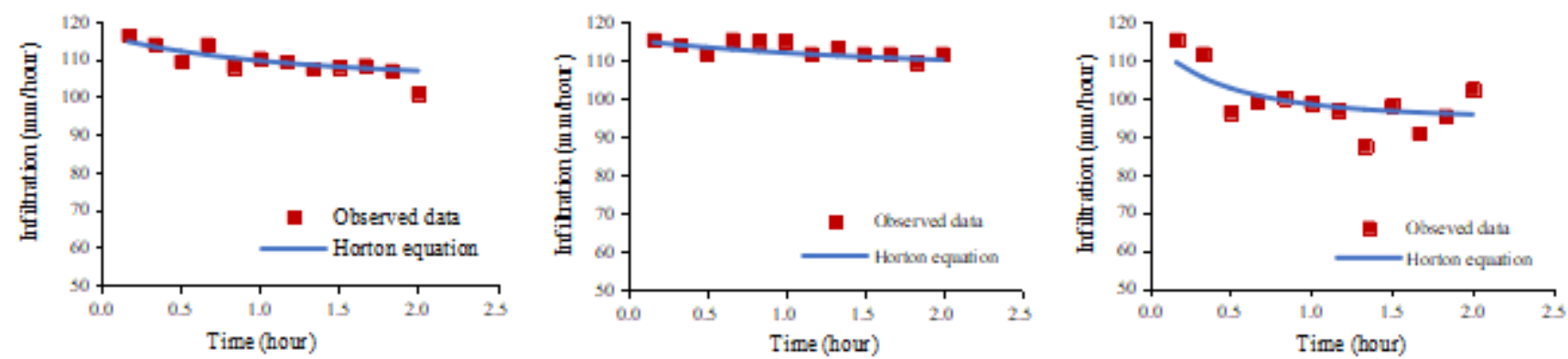

Figure 8. Optimum Horton curve for the first, second, and third (left to right) test runs on $36 \%$ slope steepness.
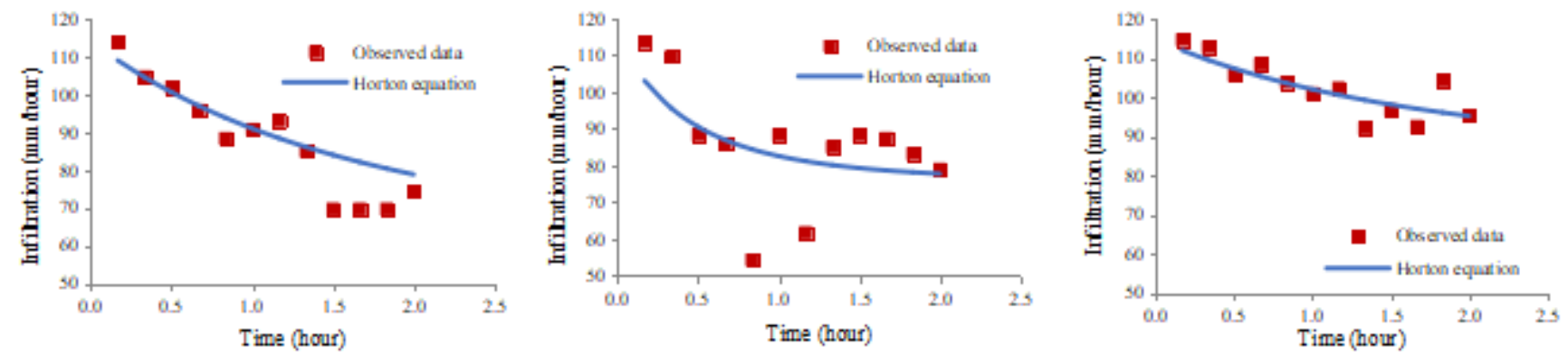

Figure 9. Optimum Horton curve for the first, second, and third (left to right) test runs on 47\% slope steepness. 

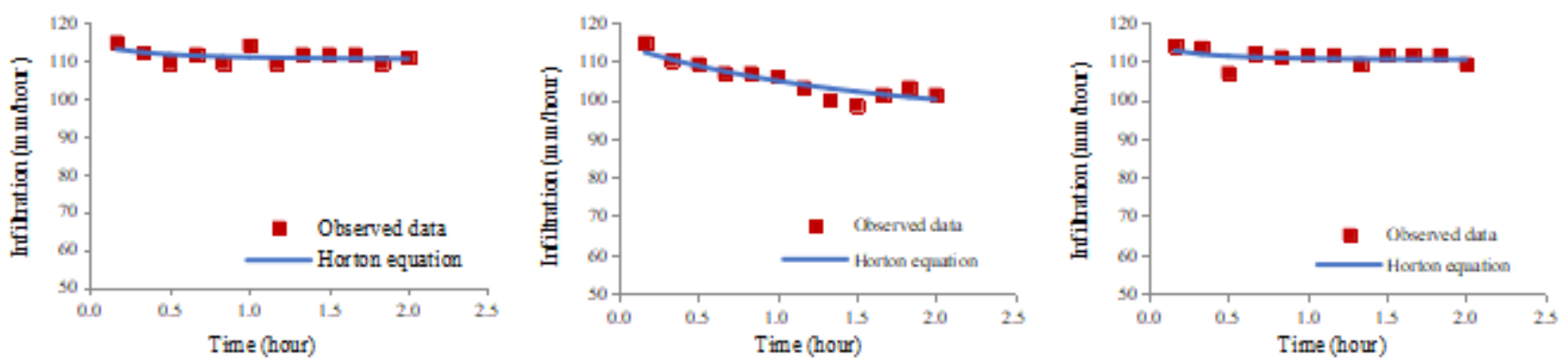

Figure 10. Optimum Horton curve for the first, second, and third (left to right) test runs on $58 \%$ slope steepness.

\subsection{Erosion Experiment Results}

The erosion test was conducted to determine the amount of erosion obtained from combining raindrop splash and sheet flow runoff for the three slope steepness values. The erosion dynamic curves for each slope with average rainfall intensity of $116.312 \mathrm{~mm} /$ hour are shown in Figure 11 while the erosion rate was obtained in gram $/ \mathrm{m}^{2} /$ minute from the collected erosion mass divided by the flume area and the test duration time.

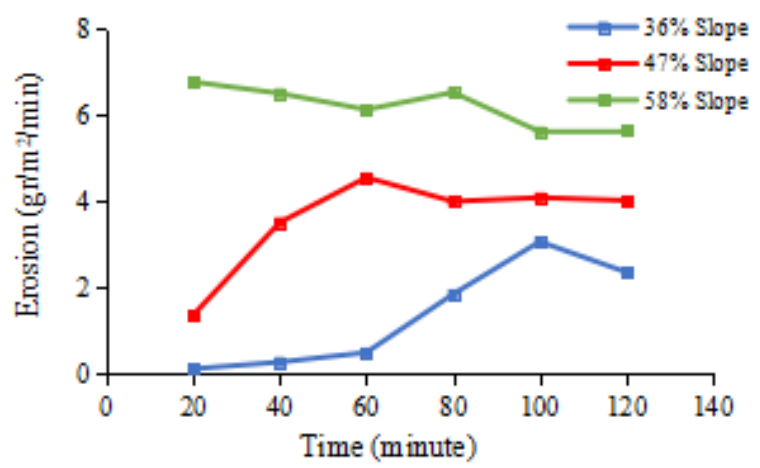

Figure 11. Erosion dynamic curves on the three slope steepness values.

The curves in Figure 11 show the growth of erosion rate during the experiment periods for different slopes and erosion observed to be occurring at the same time with infiltration is believed to be interacting with each other. This means the erosion process provided a more dominant effect on infiltration rather than otherwise.

\section{DISCUSSION}

\subsection{Observation of Infiltration and Erosion} Mechanism

Some phenomena were observed during the experiment. Firstly, the soil seems to be compacted probably due to the impact of raindrops, and this further reduced the soil surface elevation in some places. Secondly, a color difference was discovered between the unsaturated and saturated soils as shown in Figure 12.

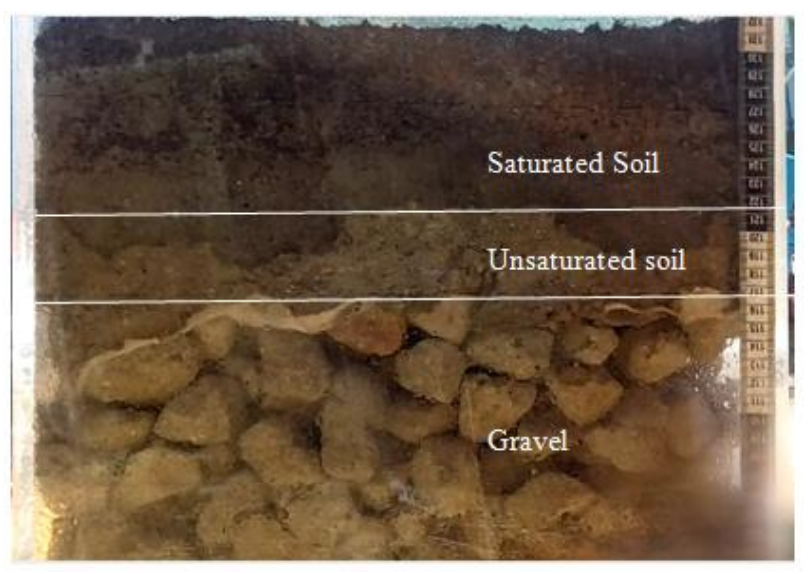

Figure 12. The color difference between the unsaturated and saturated soil.

The border of the two colors in Figure 12 indicates the extent to which water has infiltrated the soil and this further shows the progress of the infiltration front. Thirdly, the subsurface flows were found to be occurring in the completely saturated area of the soil where there are no more empty soil pores to be filled but the water passes through them. The ability of the water to pass through the soil pore after saturation was used to determine the infiltration capacity at this stage.

The soil particles on the surface were observed to be detached and transported to a downstream neighbor due to raindrop splash and surface flow during rainfall. At the upstream zone, there was no supply of soil particles and this immediately shows the existence of erosion. 
Meanwhile, some cavities appeared, filled with water, and the accumulated water formed thicker runoff which dragged the soil particles to the surface. The lack of sufficient resistance for the soil particles from inertia, friction, and cohesion led to their transportation and movement by the flow to create a rill erosion.

\subsection{The Effect of Slope Steepness on Infiltration Capacity}

The infiltration test showed the infiltration capacity was varied between $58.00 \mathrm{~mm}$ /hour and $109.32 \mathrm{~mm} /$ hour for each slope steepness as shown in Figure 13. A polynomial equation of relationship was found between slope and infiltration capacity as presented in Equation (7).

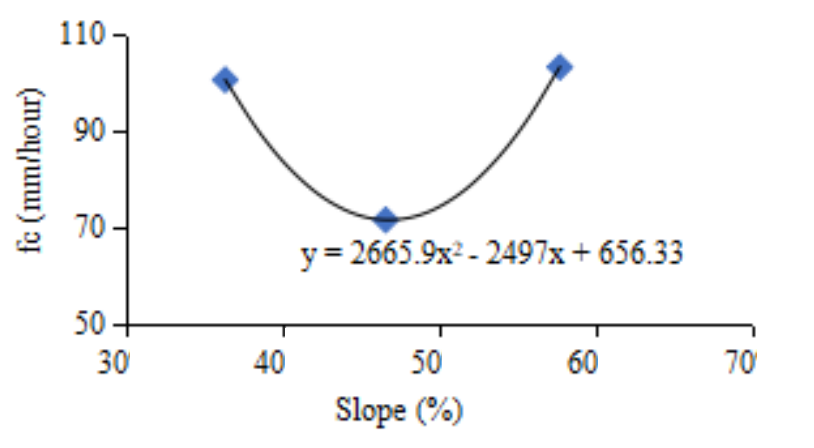

Figure 13. Relationship between mean $f_{c}$ and slope graph.

$y=2665.9 x^{2}-2497 x+656.33$

where $y$ is the infiltration capacity, $f_{c}$ ( $\mathrm{mm} /$ hour), and $x$ is the slope steepness (\%).

The relationship between the mean $f_{c}$ and slope chart shows the infiltration capacity decreased from $36 \%$ to $47 \%$ slope but increased from $47 \%$ to $58 \%$ slope. The reduction was in the infiltration capacity due to the increment in the slope value at a lower range was explained by Chaplot and Le Bissonnais (2000) to be due to the sine and cosine effect of the slope to the gravitational force.

An increment in the slope steepness or sine value and a decrease in the cosine value have been explained to be causing an increase in the flow velocity and this further reduces the chance of water to infiltrate. Moreover, an increment in the slope has also been reported to be causing a reduction in surface storage, therefore, leading to a decrease in the quantity of water to be accumulated on the soil (Mu et al., 2015).

An increase in the infiltration capacity based on an increment in the slope steepness is understood to due to the reduced rainfall density per unit area or the sloping area which causes a reduction in the effective rainfall on the plot. (Rudolph, Helming and Diestel, 1997), however, defined an effective rainfall as the vertical rain intensity multiplied by the cosine of the slope steepness and its reduction causes a decrease in the kinetic energy of raindrops in the vertical direction (Janeau et al., 2003). This further reduces soil compaction due to raindrop. Moreover, significant changes were observed to be appearing more in soil surface with $58 \%$ slope steepness compared to the others due to the interaction between runoff, erosion, and temporal deposition. These changes caused dynamic irregularities of surface soil form and the data measured during the test as indicated with the percentage of efficiency value which was relatively lower in comparison with the other slope steepness values. This phenomenon was also observed in the research conducted by Jiang et. al (2014).

The relationship between the average $f_{c}$ of the three trials and slope steepness showed the sample with $47 \%$ was the saddle point because the value lower and higher than this figure provides a higher infiltration capacity. Moreover, the existence of this minimum infiltration capacity along with the variation of slope steepness shows the interaction between several mechanisms such as raindrop, runoff pattern, rill, and cavity which has a significant influence on the infiltration capacity of slope steepness higher than $47 \%$.

\subsection{The Effect of Slope Steepness on Erosion Rate}

The test showed the average erosion value increased at a higher slope as indicated in Figure 14. Moreover, the relationship between slope and erosion based on the conditions 
applied in the study was found to be linear as shown in Equation (8).

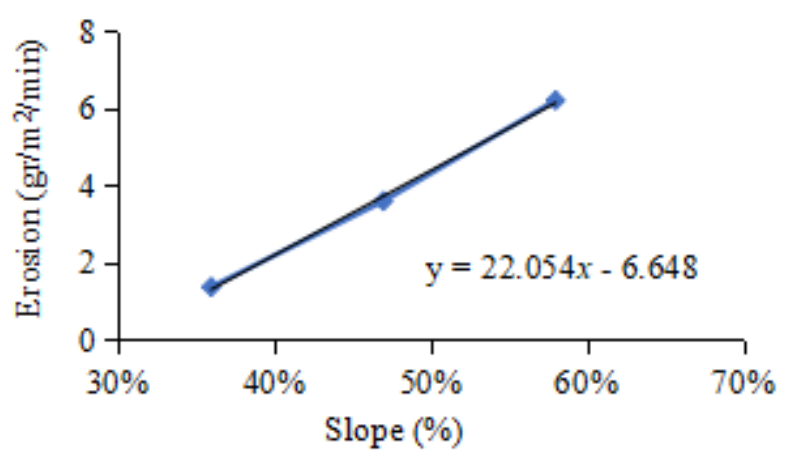

Figure 14. Erosion dynamic curves for the three slope steepness values (left) and erosion vs slope (right).

$y=22.054 x-6.648$

where, $y$ is the average erosion in concentration ( $\mathrm{gram} / \mathrm{m}^{2} / \mathrm{min}$ ) and $x$ is slope steepness (\%).

The erosion was observed to be high at higher slope steepness due to the increase in the surface flow velocity which is greater than the carrying capacity (Fox and Bryan, 2000). An increment was observed in the erosion at 58\% due to the decrease in the kinetic energy of raindrops affecting the soil surface vertically and which consequently reduced the soil compaction (Assouline and Ben-Hur, 2006; Janeau et al., 2003). This further caused more erosion on the soil surface even though the surface runoffs were lower than the values recorded at $47 \%$.

\section{CONCLUSION AND RECOMMENDATIONS}

\subsection{Conclusion}

Several conclusions were drawn from the experiment conducted and they are stated as follows.

a. Several phenomena were observed with the infiltration mechanism such as the compaction of the soil surface due to the impact of the raindrop, inability to indicate the progress of infiltration front by observing the color differences in the unsaturated and saturated soils, and the occurrence of subsurface flow after the soil has been saturated. There was, however, no appearance of impounding.

b. Two main causes of erosion were identified to be raindrops impact and surface flow and types of erosion used in the experiment were raindrop splash, sheet, and rill erosions.

c. A second-order polynomial was found to be the best type of equation to represent the relationship between slope steepness and infiltration capacity while a linear equation is the most appropriate for slope steepness and erosion rate and was effectively used in slope steepness between $36 \%$ and $58 \%$.

d. The infiltration test showed the changes in the slope steepness caused the increase and decrease in infiltration capacity. An increase from $36 \%$ to $47 \%$ was discovered to have reduced the infiltration capacity while an increment was recorded from $47 \%$ to $58 \%$. This was possibly associated with the non-uniform sheet and rill erosion which change the surface of the soil material layer to become more irregular and also provide more runoff water for infiltration at slope steepness higher than $47 \%$.

e. The erosion test showed the average erosion value increased at higher slope steepness with the increment recorded at $47 \%$ associated with the increase in surface flow velocity. The increment was also recorded at $58 \%$ even though the kinetic energy of raindrops which impacted the soil surface reduced. This means the increase in the runoff flow velocity plays a more important role in the erosion mechanism.

\subsection{Recommendation}

Several suggestions were made as follows for further studies.

a. More tests are needed for the refine slope steepness variation to ensure the relationship between the infiltration capacity, erosion, and slope steepness on Mt. Merapi bare slope material is more understood.

b. Further research on the effect of rainfall intensity, material density, water content, 
duration of rain, and others on the infiltration capacity and erosion as well as the interactions between these factors on Mt. Merapi bare slope material is needed.

c. Research on the effect of test scale on infiltration and erosion tests on Mt. Merapi bare slope material is also required.

\section{DISCLAIMER}

The authors declare no conflict of interest.

\section{ACKNOWLEDGEMENT}

This study was facilitated by the laboratory of the Sabo Agency of the Ministry of Public Works and Housing and the authors appreciate this support greatly.

\section{REFERENCES}

Ariesta, D., 2019. The Effect of Initial Groundwater Table and Rainfall Wetting Towards Slope Stability (Case Study of Landslide in Tangkil Hamlet, Banaran Village, Pulung Subdistrict, Ponorogo Regency). Journal of the Civil Engineering Forum, 5(2), p.149.

Assouline, S. and Ben-Hur, M., 2006. Effects of rainfall intensity and slope gradient on the dynamics of interrill erosion during soil surface sealing. Catena, 66(3), pp.211-220.

Bedient, P.B. and Huber, W.C., 1992. Hydrology and Floodplain Analysis. Addision.

De Bélizal, E., Lavigne, F., Hadmoko, D.S., Degeai, J.-P., Dipayana, G.A., Mutaqin, B.W., Marfai, M.A., Coquet, M., Le Mauff, B. and Robin, A.-K., 2013. Rain-triggered lahars following the 2010 eruption of Merapi volcano, Indonesia: A major risk. Journal of Volcanology and Geothermal Research, 261, pp.330-347.

BNPB, 2016. Badan Nasional Penanggulangan Bencana [online].

Chaplot, V. and Le Bissonnais, Y., 2000. Field measurements of interrill erosion under different slopes and plot sizes. Earth Surface Processes and Landforms: The Journal of the British Geomorphological Research Group, 25(2), pp.145-153.
Christiansen, J.E., 1942. Irrigation by sprinkling. University of California Berkeley.

Ekwue, E.I. and Harrilal, A., 2010. Effect of soil type, peat, slope, compaction effort and their interactions on infiltration, runoff and raindrop erosion of some Trinidadian soils. Biosystems Engineering, 105(1), pp.112-118.

Farmer, E.E., 1971. Soil erosion by overland flow and raindrop splash on three mountain soils. Intermountain Forest \& Range Experiment Station, Forest Service, US ....

Fathani, T.F., Syah, A. and Faris, F., 2019. A Numerical Analysis of Landslide Movements Considering the Erosion and Deposition along the Flow Path. Journal of the Civil Engineering Forum, 5(3), p.187.

Fox, D.M. and Bryan, R.B., 2000. The relationship of soil loss by interrill erosion to slope gradient. Catena, 38(3), pp.211-222.

Harto, S., 2000. Hidrologi. Nafiri Offset. Yogyakarta.

Horton, R.E., 1933. The role of infiltration in the hydrologic cycle. Eos, Transactions American Geophysical Union, 14(1), pp.446-460.

Janeau, J.-L., Bricquet, J.-P., Planchon, O. and Valentin, C., 2003. Soil crusting and infiltration on steep slopes in northern Thailand. European Journal of Soil Science, 54(3), pp.543-554.

Jiang, F., Huang, Y., Wang, M., Lin, J., Zhao, G. and Ge, H., 2014. Effects of rainfall intensity and slope gradient on steep colluvial deposit erosion in southeast China. Soil Science Society of America Journal, 78(5), pp.1741-1752.

Jones, R., Thomas, R.E., Peakall, J. and Manville, V., 2017. Rainfall-runoff properties of tephra: Simulated effects of grain-size and antecedent rainfall. Geomorphology, 282, pp.39-51.

Joshi, V.U. and Tambe, D.T., 2010. Estimation of infiltration rate, run-off and sediment yield under simulated rainfall experiments in upper Pravara Basin, India: Effect of slope angle and grass-cover. Journal of earth system science, 
119(6), p.763.

Lei, T., Pan, Y., Liu, H., Zhan, W. and Yuan, J., 2006. A run off-on-ponding method and models for the transient infiltration capability process of sloped soil surface under rainfall and erosion impacts. Journal of Hydrology, 319(1-4), pp.216226.

Liu, H., Lei, T.W., Zhao, J., Yuan, C.P., Fan, Y.T. and Qu, L.Q., 2011. Effects of rainfall intensity and antecedent soil water content on soil infiltrability under rainfall conditions using the run off-on-out method. Journal of Hydrology, 396(1-2), pp.24-32.

Miedema, S.A., 2012. Constructing the Shields curve. Part A: Fundamentals of the sliding, rolling and lifting mechanisms for the entrainment of particles. J. Dredging Eng, 12(December), pp.1-49.

Mu, W., Yu, F., Li, C., Xie, Y., Tian, J., Liu, J. and Zhao, N., 2015. Effects of rainfall intensity and slope gradient on runoff and soil moisture content on different growing stages of spring maize. Water, 7(6), pp.2990-3008.

Ningsih, S. and Purnama, I.L.S., 2012. Kajian Laju Infiltrasi Tanah Dan Imbuhan Airtanah Lokal Sub DAS Gendol Pasca Erupsi Merapi 2010. Jurnal Bumi Indonesia, 1(2).

Prayuda, D.D., 2012. Temporal and spatial analysis of extreme rainfall on the slope area of Mt. Merapi. Civil Engineering Forum, XXI(September), pp.1285-1290.

Ran, Q., Wang, F., Li, P., Ye, S., Tang, H. and Gao, J., 2018. Effect of rainfall moving direction on surface flow and soil erosion processes on slopes with sealing. Journal of Hydrology, 567, pp.478-488.

Ribolzi, O., Patin, J., Bresson, L.-M., Latsachack,
K.O., Mouche, E., Sengtaheuanghoung, O., Silvera, N., Thiébaux, J.-P. and Valentin, C., 2011. Impact of slope gradient on soil surface features and infiltration on steep slopes in northern Laos. Geomorphology, 127(1-2), pp.53-63.

Rudolph, A., Helming, K. and Diestel, H., 1997. Effect of antecedent soil water content and rainfall regime on microrelief changes. Soil technology, 10(1), pp.69-81.

Della Sala, M., 2014. Genesis and mechanism of rainfall-induced hyperconcentrated flows in granular soils.

Santosh, K.G., 2007. Irrigation engineering and hydraulic structures.

Schor, H.J. and Gray, D.H., 2007. Landforming: an environmental approach to hillside development, mine reclamation and watershed restoration. John Wiley \& Sons.

Selles, A., 2014. Multi-disciplinary study on the hydrogeological behaviour of the Eastern flank of the Merapi Volcano, Central Java, Indonesia.

Smount, I.K., 1994. Soil and Water Conservation Engineering, by GO Schwab, DD Fangmeier, WJ Elliot \& RK Frevert. xiv+ 507 pp. Chichester: John Wiley \& Sons (1993).£ 16.95 (paperback), £ 57.00 (hardback). ISBN $00471 \quad 59994 \quad 8$ (paperback). ISBN 0471574902 (hardback). The Journal of Agricultural Science, 123(2), pp.294295.

Triatmodjo, B., 2008. Hidrologi Terapan. Beta Offset, Yogyakarta.

Wang, L., Dalabay, N., Lu, P. and Wu, F., 2017. Effects of tillage practices and slope on runoff and erosion of soil from the Loess Plateau, China, subjected to simulated rainfall. Soil and Tillage Research, 166, pp.147-156. 
[This page is intentionally left blank] 